\title{
Liquidity Risk and Financial Performance of Commercial Banks in Kenya
}

\author{
Jane Gathigia Muriithi ${ }^{1} \&$ Kennedy Munyua Waweru ${ }^{2}$ \\ ${ }^{1}$ School of Business, Jomo Kenyatta University of Agriculture and Technology, Kenya \\ ${ }^{2}$ Shool of Business and Economics, The Co-operative University of Kenya, Kenya \\ Correspondence: Jane Gathigia Muriithi, School of Business, Jomo Kenyatta University of Agriculture and \\ Technology, Department of Economic, Accounting and Finance, P. O. Box 62000-00200, Nairobi, Kenya. E-mail: \\ jkimuu@yahoo.com
}

Received: January 10, 2017

Accepted: February 22, 2017

Online Published: February 25, 2017

doi:10.5539/ijef.v9n3p256

URL: https://doi.org/10.5539/ijef.v9n3p256

\begin{abstract}
The focus of this study was to examine the effect of liquidity risk on financial performance of commercial banks in Kenya. The period of interest was between year 2005 and 2014 for all the 43 registered commercial banks in Kenya. Liquidity risk was measured by liquidity coverage ratio (LCR) and net stable funding ratio (NSFR) while financial performance by return on equity (ROE). Data was collected from commercial banks' financial statements filed with the Central Bank of Kenya. Panel data techniques of random effects estimation and generalized method of moments (GMM) were used to purge time-invariant unobserved firm specific effects and to mitigate potential endogeneity problems. Pairwise correlations between the variables were carried out. Wald and F- tests were used to determine the significance of the regression while the coefficient of determination, within and between, was used to determine how much variation in dependent variable is explained by independent variables. Findings indicate that NSFR is negatively associated with bank profitability both in long run and short run while LCR does not significantly influence the financial performance of commercial banks in Kenya both in long run and short run. However, the overall effect was that liquidity risk has a negative effect on financial performance. It is therefore advisable for a bank's management to pay the required attention to the liquidity management.
\end{abstract}

Keywords: liquidity risk, liquidity coverage ratio, net stable funding ratio, return on equity

\section{Introduction}

Liquidity risk in commercial banks is defined as the possibility that over a specific horizon, the bank will become unable to settle obligations with immediacy (Drehmann \& Nikolaou, 2013). In commercial banks this risk is specially related to funding. The risk arises from management's inability to adequately anticipate and plan for changes in funding sources and cash needs (Ogol, 2011). Efficient liquidity management therefore requires maintaining sufficient cash reserves on hand while also investing as many funds as possible to maximize earnings. As Goodhart (2008) infers, there are two basic facets of liquidity risk. These are maturity transformation which is the maturity of a bank's liabilities and assets and the inherent liquidity of a bank's asset described as the extent to which an asset can be sold without incurring a significant loss of value under any market condition. Banks do not need to be worried about the maturity transformation if they have the assets that can be sold without bearing any loss. Whereas, banks having assets that are going to be matured in a shorter period may have a less need to keep the liquid assets (Ahmed et al., 2015).

Liquidity risk may arise due to liquidity mismatch which is measured in terms of liquidity gap. Liquidity gap is described as the of difference between a bank's assets and a bank's liabilities (Falconer, 2001; Plochan, 2007). This gap can be positive or negative. A negative gap means that the bank is netting less income than the amount of liabilities assumed. When the gap is positive, the bank has liquid assets left over after all of the liabilities have been covered. This is one way of measuring the organization's level of financial risk (Central Bank of Barbados, 2008; Brunnermeier \& Yogo, 2009). Apart from the foregoing maturity mismatch, liquidity risk arises due to recessionary economic conditions, causing less resource generation. This increases the demand of depositors creating liquidity risk. This may cause the failure of a given bank or even the entire banking system due to contagion effect. Liquidity risk may also arise due to the breakdown or delays in cashflows from the borrowers 
or early termination of the projects (Diamond \& Rajan, 2005).

\section{Literature Review}

The pivotal role played by commercial banks in the financial system and monetary system in general (Drigă \& Dura, 2014) has led to significant research attention on the various risks that may impinge on their stability and liquidity risk is not an exception. Ashraf et al. (2015) use generalized method of moments (GMM) model to examine the effectiveness of Basel III by linking the net stable funding ratio (NSFR) with overall financial stability by analyzing annual financial data from 948 banks in 85 countries (excluding banks from North America and Europe) from 2003 to 2013. The study found a positive and statistically significant relationship between the NSFR and Z -score as a proxy for financial stability of banks. Bordeleau et al. (2009) on the hand assess the impact of liquidity on bank profitability for 55 US banks and 10 Canadian banks between the period of 1997 and 2009. The study employed quantitative measures to assess the impact of liquidity on bank profitability. Results from the study suggest that a nonlinear relationship exists, whereby profitability is improved for banks that hold some liquid assets, however, there is a point beyond which holding further liquid assets diminishes a banks' profitability, all else equal.

Country specific studies on liquidity include Adolphus (2008) who in a study of selected Nigerian banks confirms the finding by Bordeleau et al. (2009). Koziol et al. (2008) employ a regression model to assess the risk of bank failures in Islamic Banks of Brunei. They show that risk identification, risk assessment and risk analysis were the most influencing variables. Akhtar (2011) on the other hand examines the association of liquidity risk with the solvency of a financial institution through a comparative analysis between conventional and Islamic banks in Pakistan from 2006 to 2009. The study found positive but insignificant relationship of size of the bank and net-working capital with liquidity risks. Still in Pakistan, Ahmed et al. (2012) use multiple regressions examine liquidity risk and its effect on banks' profitability in 22 Pakistani banks during 2004 to 2009. Their study's results suggest that liquidity risk affects bank profitability significantly. Liquidity gap and non-performing assets are the two factors exacerbating the liquidity risk as they have a negative relationship with profitability. In Malaysia, Said (2014) employ Pooled Ordinary Least Squares (POLS) and Fixed Effect estimations to analyze the impact of NSFR on Malaysian commercial banks profitability for the period 2005-2011. They show that there exist positive relationships between NSFR and indicators of performance which were return on equity (ROE), return on assets (ROA) and net interest margin (NIM). Other studies include those of Giannotti et al. (2011), Angora, and Roulet (2011) and Giordana, and Schumacher (2012).

The liquidity risk in commercial banks in Kenya, a country which currently has 42 commercial banks down from 44 in the year 2012 has also received research attention. Wambu (2013) use the LCR and current ratio to investigate whether the profitability of commercial banks is affected by the liquidity levels of all the 44 commercial banks for the years 2008 to 2012 . The study finds a positive relationship between profitability and liquidity of commercial banks in Kenya. Musembi, Ali, and Kingi, (2016), Ogilo and Mugenyah, (2015) Ouma, (2015) and Maaka (2013) use similar measures of liquidity and different sample sizes to study effects of liquidity risk on profitability of commercial banks in Kenya. Ogol (2011) on the other hand investigates liquidity risk management practices in microfinance institutions in Kenya using a descriptive research design. Unlike other studies in this area, (Giannotti et al., 2011; Angora \& Roulet, 2011; Giordana \& Schumacher, 2012), The studies on liquidity in Kenyan commercial banks studies do not consider NSFR and only one considers LCR. These variables are the two dependent variables considered by this study, and are the two liquidity measures proposed in the Basel III framework. This study employs the time series cross section data using NSFR and LCR measures of liquidity risk to investigate is effect on financial performance.

\section{Methodology}

The study used quantitative research design. LCR and NSFR were computed for each commercial bank and were then transformed into unbalanced panels. Panel data estimation technique was adopted because it takes care of heterogeneity associated with individual banks by allowing for individual specific variables. Further, by combining time series of cross sectional observations, panel data provides more informative data, more variability, less collinearity among variables, more degrees of freedom and more efficiency. Besides, panel data minimizes the bias that can result if individual banks are aggregated. It also enriches empirical analysis in such a way that may not be possible if either only time series data or cross sectional data is used (Ogboi \& Unuafe, 2013). The target population of the study comprised of all the 43 licensed commercial banks in Kenya by December 2014. The study employed secondary data that was extracted from audited financial statements and annual reports of commercial banks over the 10-year period, 2005 to 2014. Data collection was carried out in the month of November 2015. 


\subsection{Model Specification}

The independent variables and the dependent variable were assumed to have a general multiplicative Cobb Douglas functional relationship shown in equation 1.

$$
R O E=f(L C R, N S F R)
$$

Upon linearization and parametrization, the long run model for functional form 3.5 was specified as:

$$
R O E_{i, t}=\lambda_{0}+\lambda_{1} L C R_{i, t}+\lambda_{2} N S F R_{i, t}+\theta_{i}+\varepsilon_{i, t}
$$

And the short run model as:

$$
R O E_{i, t}=\lambda_{0}+\beta R O E_{i t-1}+\lambda_{1} L C R_{i, t}+\lambda_{2} N S F R_{i, t}+\theta_{i}+\varepsilon_{i, t}
$$

$R O E_{i, t}$, represents the return on equity used as the measure of performance of bank $i$ at time $t, \lambda_{0}$ stands for the model constant or intercept, $\lambda_{i}$ stands for the coefficients of the independent variables. ROE $E_{i t-1}$ is lagged bank performance, $L C R_{i, t}$ is the Liquidity Coverage ratio of bank $i$ at time $t, N S F R_{i, t}$ is the Net Stable Funding Ratio of bank $i$ at time $t$, and $\varepsilon_{i, t}$ is the error term which is assumed to have a normal distribution. $\theta_{i}$ is the bank specific effect that is assumed to be normally distributed with a constant variance. $\mathcal{E}_{i t}$ is the idiosyncratic error term, assumed to have a normal distribution. The linearization process involved logging the variables. Therefore, all the variables enter models 2 and 3 in $\log$ form. This inherently made the $\beta$ and the $\lambda_{i}^{\prime}$ s elasticities.

\subsection{Measurement of Variables}

ROE not only goes up by increasing shareholder's returns but also grows by taking more debt and thus bearing more risk. Risk management becomes more and more significant to ensure sustainable profits in commercial banks (Hosna et al., 2009). ROE was measured in terms equation 4.

$$
R O E=\frac{\text { Net Income }}{\text { Shareholder's Equity }}
$$

Basel III describes that LCR requires that banks hold high quality liquid assets to meet liquidity needs over a 30-day time horizon under an acute liquidity stress scenario. The LCR is thus a constraint on how much short-run liquidity risk a bank is allowed to hold. It is supposed to "promote short-term resilience of a bank's liquidity risk profile by ensuring that it has sufficient high-quality liquid assets to survive a significant stress scenario lasting for one month. LCR was measured in terms of equation 5.

$$
L C R=\frac{\text { High Quality Liquid Assets }}{\text { Outflows-min }(\text { Inflows, } 0.75 * \text { Outflow })}
$$

The NSFR is defined by Basel III as the amount of available stable funding relative to the amount of required stable funding. The standard requires a minimum amount of funding that is expected to be stable over a one year time horizon based on liquidity risk factors assigned to assets and off-balance sheet liquidity exposures. This ratio is intended to promote longer-term structural funding of banks' balance sheets, off-balance sheet exposures and capital markets activities. This ratio should be equal to at least $100 \%$ on an on-going basis. Available stable funding comprises of capital and liabilities expected to be reliable over the time horizon considered by the NSFR, which extends to one year. The amount of such stable funding required of comprises of Cash, Short-term unsecured traded instruments and as well as those of its off-balance sheet (OBS) exposures. NSFR was measured as per equation 6.

$$
N S F R=\frac{\text { Available amount of stable funding }}{\text { Required amount of stable funding }}
$$

Table 1 gives the average the overall mean for ROE, LCR and NSFR. The mean of ROE of 17.8 per cent is an indication that banks are competing among them for making profit however their standard deviations of 17.0 percent evident that their profit-making capacity is divergent from each other. The mean LCR and NSFR were, 46.1 and 320.3 per cent respectively. Therefore, on average the banks created more money from their deposits and sufficiently met liquidity requirements. The average liquidity coverage ratio of Kenyan banks was 46.1 percent with standard deviation of 28.1 percent. The maximum and minimum values were 18.8 percent and 459.0 percent respectively. This indicates high liquidity which could be attributed to the fact that commercial banks require higher liquidity levels to satisfy the customer cash needs which are commonly on random demand. Available amount of stable funding is much higher than the required amount of stable funding for the commercial banks during the period of the study. Available amount of Stable Funding comprises of the bank's capital, preferred stock and liabilities with maturities greater than or equal to one year while required amount of stable funding is calculated as the weighted sum of the value of assets held and funded by the entity including off-balance sheet exposures. 
Table 1. Summary statistics for the secondary data set

\begin{tabular}{lccccc}
\hline Variables & $\mathrm{N}$ & Mean & Standard Deviation & Min & Max \\
\hline ROE & 416 & 0.178 & 0.170 & -0.909 & 0.500 \\
LCR & 414 & 0.461 & 0.281 & 0.188 & 4.590 \\
NSFR & 414 & 3.203 & 3.068 & 0.645 & 38.06 \\
\hline
\end{tabular}

To establish the distribution the variables, the one-way error components for panel data an extension of the classical Bera-Jarque test by Galvao, Montes-Rojas, Sosa-Escudero and Wang (2013) was conducted. The test was used to verify whether the analysis of the variance of the error term could be used to test significance of the coefficient. Table 2 presents the pairwise correlation between the components of the liquidity risk. Only the NSFR was found to be significantly correlated with return on equity. The correlation coefficient is -0.293 with a p-value less than 0.01. This suggests that the coefficient of NSFR in the regressions will be negative. The coefficient of LCR is 0.050 with a p-value greater than 0.1 . Therefore, the correlation coefficient was not significant at one per cent level of significance. Thus, the study could not establish a prior what signage the coefficient of LCR will have and whether it will be significant. There was also negative correlation coefficient between NSFR and LCR. The correlation coefficient is -0.202 with a p-value less than 0.01 . Thus, the correlation coefficient was significant at one per cent level of significance.

Table 2. Correlation between liquidity risk components and return on equity

\begin{tabular}{lccc}
\hline & ROE & NSFR & LCR \\
\hline ROE & 1 & & \\
NSFR & -0.293 & 1 & \\
& $(0.000)$ & & 1 \\
LCR & 0.050 & -0.202 & \\
& $(0.334)$ & $(0.000)$ &
\end{tabular}

Note. P-values in parenthesis. ROE represent return on equity, LCR represents Liquidity. Coverage ratio and NSFR represents net stable funding ratio.

The extension of the Bera-Jarque normality test by Galvao, Montes-Rojas, Sosa-Escudero and Wang (2013) made the normality test a standard test that can be performed prior to the estimation of the model or even after the estimation of the model. The normality test of each of the components in the error term is shown in table 4 . The individual specific heterogeneity component is $\boldsymbol{u}$ while the rest of the error term is $e . u$ varies within banks only while $\boldsymbol{e}$ varies across banks and time. To use the variance of the combined error term to test the significance of the coefficients in the estimates of the model requires that each component is normally distributed. Therefore, the skewness and kurtosis of the components should be symmetrical to that of the normal distribution. Table 3 shows that the $\mathrm{z}$ statistics for kurtosis of all the components of the error terms in all the models have p-values greater than 0.1. Therefore, the $\mathrm{z}$ statistics are less than the tabulated statistics at five per cent level of significance. Thus, the null hypothesis that each components kurtosis is symmetric to that of the normal distribution is not rejected at five per cent level of significance. Therefore, the components of the error term are neither more nor less peaked than the normal distribution. The overall normality test of each component of the error term in model has chi statistics with corresponding p-value that are greater than 0.1 . Therefore, the chi statistics are less than the critical values at five per cent level of significance. Consequently, the null hypothesis that each component is normally distributed is not rejected at five per cent level of significance for all the models. These results therefore indicate that the error components are normally distributed for each model.

Table 3. Skewness Kurtosis and normality of one-way error component for panel models

\begin{tabular}{ccccccc}
\hline & \multicolumn{2}{c}{ Skewness } & \multicolumn{2}{c}{ Kurtosis } & \multicolumn{2}{c}{ Normality } \\
\cline { 2 - 6 } Error Component & Z Statistic & P-Value & Z Statistic & P-Value & Chi Statistic & P-Value \\
\hline $\mathrm{e}$ & -1.46 & 0.144 & 2.36 & 0.328 & 7.69 & 0.1214 \\
$\mathrm{u}$ & -2.2 & 0.078 & 1.57 & 0.116 & 7.33 & 0.0656 \\
\hline
\end{tabular}

Table 3 shows the distribution of the one-way error component in the linear panel model 1 . The individual specific heterogeneity component is $\mathrm{u}$ while $\mathrm{u}$ is the error term. $\mathrm{u}$ varies with banks only while e varies across banks and time. To use the variance of the combined error term to test the significance of the coefficients in the estimates of the model requires that each component is normally distributed. Therefore, the skewness and kurtosis of the components should be symmetrical to that of the normal distribution. Table 3 shows that the $\mathrm{z}$ 
statistic for the skewness of the two components in model 1 have $\mathrm{z}$ statistics with corresponding $\mathrm{p}$-values that are greater than 0.01 . Thus, the $\mathrm{Z}$ statistics are less than the tabulated at five per cent level of significance. Therefore, the null hypothesis of symmetrical skewness with normal distribution is not rejected for any component in all the models. Thus, the components are neither negatively nor positively skewed compared to the normal distribution.

The test further shows that the $\mathrm{z}$ statistics for kurtosis of the components of the error terms in the model have $\mathrm{p}$-values greater than 0.1 . Therefore, the $\mathrm{z}$ statistics are less than the tabulated statistics at five per cent level of significance. Thus, the null hypothesis that each components kurtosis is symmetric to that of the normal distribution is not rejected at five per cent level of significance. Therefore, the components of the error term are neither more nor less peaked than the normal distribution. The overall normality test of each component of the error term in model 1 has chi statistics with corresponding p-value that are greater than 0.1 . Therefore, the chi statistics are less than the critical values at five per cent level of significance. Thus, the null hypothesis that each component is normally distributed is not rejected at five per cent level of significance for all the models. Therefore, the error components are normally distributed for each model. The fact that the one-way error component model is normally distributed in model 1 implies that the study could reliably use the standard errors and $\boldsymbol{t}$-statistics. The use of standard errors and $\boldsymbol{t}$-statistics to test for the significance of coefficients is based on Gaussianicity of the error term. An assumption satisfied by the errors from the panel data model.

\section{Findings}

The findings are presented as follows; the long run model is presented separately and its post-estimation diagnostics discussed to establish the reliability of the findings, the study discriminates between the long run models using Hausman test and presents the naïve OLS and fixed effects estimates of the short run specification to establish the range where the coefficient of lagged return on equity should lie in the GMM specification. The study estimates and presents the GMM specification while presenting the instruments used and discussing the post-estimation diagnostics of the GMM model. Finally, a comparative summary of all the models and tests the hypothesis both in the short and in the long run is presented.

The first long run specification of the model was the fixed effects model whose findings are shown in table 4 . The table indicates that the F statistic is 3.67 and is greater than the critical value at one per cent level of significance. Therefore, the variables (liquidity risk components) are jointly significant in explaining the variations in return on equity. The interclass correlation (rho) is 65.5 per cent implying that 65.5 per cent of the variations in return in equity are due to differences across the banks. The within and between R-square is 2.1 per cent and 18.5 per cent respectively. Thus, 2.1 per cent of variations in the return on equity are due to differences within individual banks and 18.5 per cent of the variations are due to differences between the banks. The chow test statistic is 14.5 and is greater than the critical value at one per cent level of significance. Therefore, the null hypothesis that the fixed effects are equal to zero is rejected at one per cent level of significance. Thus, the option of specifying the long run version of the model as a POLS model over the fixed effects specification is rejected at one per cent level of significance.

Table 4. Fixed effects estimates

\begin{tabular}{lcc}
\hline Dependent variable & & ROE \\
\hline Explanatory Variables & & Coefficient \\
NSFR & & $-0.213^{* * * *}$ \\
LCR & & $-0.042^{* * * *}$ \\
Constant & Post Estimation Diagnostics & $-1.610^{* * * *}$ \\
\hline & Within & \\
\hline R square & Between & 0.0213 \\
& Overall & 0.1854 \\
& Rho & 0.0887 \\
F test $(2,337)$ & & 0.6548 \\
chow test & F (41,337) & $3.67^{* * *}$ \\
\hline
\end{tabular}

Note. p-value $<0.01 * * * ; \mathrm{P}$-value $<0.05 * * ; \mathrm{P}$-value $<0.1 *$.

The alternative long run specification of the model was the random effects model. The estimates for this specification are shown in Table 5. The table shows that the Wald statistic is 12.08 and is greater than the critical value at one per cent level of significance. Therefore, the variables (liquidity risk components) are jointly significant in explaining the variations in ROE in the random effects specification. The interclass correlation (rho) 
is 62.4 per cent implying that 62.4 per cent of the variations in return in equity are due to differences across the banks as per the random effects model. The within and between R-square is 2.13 per cent and 18.43 per cent respectively. Thus, 2.13 per cent of variations in the return on equity are due to differences within individual banks and 18.43 per cent of the variations are due to differences between the banks. The LM test statistic is 437.28 and is greater than the critical value at one per cent level of significance. Therefore, the null hypothesis that the cross sections are homogeneous is rejected at one per cent level of significance. Thus, the random effects specification is preferred over POLS.

Table 5. Random effects estimates

\begin{tabular}{lcc}
\hline \multicolumn{2}{l}{ Dependent variable } & ROE \\
\hline Explanatory Variable & & Coefficient \\
NSFR & & $-0.260^{* * *}$ \\
LCR & & $-0.045^{* * *}$ \\
Constant & Post Estimation Diagnostics & $-1.620^{* * *}$ \\
\hline & Within \\
\hline R square & Between & 0.0213 \\
& Overall & 0.1843 \\
& Rho & 0.0885 \\
Wald test $(3,365)$ & & 0.6235 \\
Lm test & Chibar2 & $12.08^{* * *}$ \\
\hline
\end{tabular}

Note. p-value $<0.01 * * * ;$ P-value $<0.05 * * ; \mathrm{P}$-value $<0.1 *$.

A comparison of the fixed and random effects specification reveals that the two long run models lead to similar conclusions. For instance, the overall prediction of both models is 8.9 per cent. However, Hausman test is conducted to determine which model should be interpreted in the long run. Results indicate that the test statistics have a chi statistic of 4.36 with two degrees of freedom and a corresponding $\mathrm{p}$ value of 0.1130 . Therefore, the null hypothesis that the regressors and individual heterogeneity are strictly exogenous is not rejected at one per cent level of significance. Thus, the RE specification is preferred over FE specification. Therefore, for the long run specification the random effects model should be interpreted.

To establish the bound where the coefficient of lagged profits would lie in the short run specification of model, the naïve OLS was estimated to establish the upper bound of the coefficient. The OLS estimates are shown in table 6. The table reveals that the coefficient of lagged return on equity is 0.700 . Therefore, the upper bound for the coefficient of lagged return on equity in the GMM specification of the short run model should be 0.700 . To get the lower bound the fixed effect estimates of the short run specification of the model are used.

Table 6. Short run OLS estimates for the model

\begin{tabular}{lc}
\hline Dependent variable & ROE \\
\cline { 2 - 3 } Explanatory Variable & Coefficient \\
$R O E_{t-1}$ & $0.700^{* * * *}$ \\
NSFR & $-0.139^{* *}$ \\
LCR & -0.103 \\
Constant & Post Estimation Diagnostics \\
\hline & \\
\hline R square & $-0.445^{* * *}$ \\
\hline F statistic (3,330) & 0.5940 \\
\hline
\end{tabular}

Note. p-value $<0.01 * * * ;$ P-value $<0.05 * * ; \mathrm{P}$-value $<0.1 *$.

Table 7 shows the fixed effects estimates of the short run specification of the model. The coefficient of lagged return on equity is 0.285 . Thus, the lower bound of lagged return on equity in the GMM specification should be 0.285 . Specifically, if the estimate is $\lambda$, it should lie in the interval $0.285 \leq \lambda \leq 0.700$. 
Table 7. Short run fixed effects estimates for the model

\begin{tabular}{lc}
\hline Dependent variable & ROE \\
\cline { 2 - 3 } Explanatory Variable & Coefficient \\
$R O E_{t-1}$ & $0.285^{* *}$ \\
NSFR & $-0.133^{*}$ \\
LCR & -0.096 \\
Constant & $-1.169^{* * *}$ \\
\hline & Post Estimation Diagnostics \\
\hline R square & 0.5831 \\
F statistic $(3,289)$ & $13.36^{* * *}$ \\
\hline
\end{tabular}

Note. p-value $<0.01 * * * ;$ P-value $<0.05 * * ; \mathrm{P}$-value $<0.1 *$.

The one step system GMM consistent estimates of the short run specification are shown in table 8. Results in the table indicate that the one step system GMM estimates for the short run specification of the model. The coefficient of the lagged return on equity is 0.529 . The coefficient, therefore, lies in the acceptable range of $0.285 \leq \lambda \leq 0.700$ established by the naïve OLS estimates and fixed effects estimates of the short run model, demonstrating consistency of estimates. The results further indicate that the Hansen $\mathbf{J}$ statistic is 41.53 with a corresponding $\mathrm{p}$-value greater than 0.1 . Therefore, the null hypothesis of the validity of the overidentifying restrictions for the instruments is not rejected at one per cent level of significance. Therefore, the instruments employed by the model are appropriate and lead to precise consistent estimates. Table 10 also presents the test of autocorrelation in the error terms. The AR (1), first order autocorrelation, test statistic is -3.31 and is greater than the critical value at five per cent level of significance. Therefore, the null hypothesis that disturbance term (error term) has no first order serial correlation is rejected at one per cent level of significance. This is expected because of the dynamic specification of the model and therefore, points to correct specification. The test statistic for second order serial correlation in the error term is -1.37 with a corresponding $p$-value that is greater than 0.1 . Therefore, at one per cent level of significance the null hypothesis that there is no second order serial correlation in the disturbance term is not rejected at one per cent level of significance permitting the use of instruments from the second lag and differences. This further supports the argument of correct short run specification of model using the one step system GMM estimates.

Table 8. One step system GMM estimates

\begin{tabular}{|c|c|}
\hline Dependent variable & ROE \\
\hline Explanatory Variable & Coefficient \\
\hline$R O E_{t-1}$ & $0.529 * * *$ \\
\hline NSFR & $-0.2201 * * *$ \\
\hline LCR & -0.135 \\
\hline Constant & $-0.696 * * *$ \\
\hline \multicolumn{2}{|c|}{ Post Estimation Diagnostics } \\
\hline Hansen $\mathrm{J}$ test & 41.53 \\
\hline $\mathrm{AR}(1)$ & $-3.31 * *$ \\
\hline $\mathrm{AR}(2)$ & -1.37 \\
\hline
\end{tabular}

Note. p-value $<0.01 * * * ; \mathrm{P}$-value $<0.05 * * ; \mathrm{P}$-value $<0.1$.

Table 9 gives a summary of results for the long run and short run specifications of model. The long run specification has both the fixed and random effects models. A comparison of the estimates from the two models reveals that the signage as well as the magnitude of coefficients is relatively the same for the long run models but different for the short run models. It also shows that in the long run coefficient of NSFR is -0.260 and has a corresponding $\mathrm{p}$-value that is less than 0.01 . Therefore, the coefficient is significant different from zero at one per cent level of significance. Thus, in the long run the hypothesis that NSFR has a significant negative effect on the financial performance of commercial banks in Kenya is not rejected at one per cent level of significance. The magnitude of the coefficient is 0.260 . All the variables enter equation 1 in $\log$ form therefore, the coefficients are elasticities. Thus, a one per cent increase in net stable funding reduces return on equity by 26.0 percentage points ceteris paribus. In the short run the coefficient of NSFR is -0.221 with a p-value that less than 0.01 . Hence the coefficient is significant and negative at one per cent level of significance. The magnitude of the coefficient is 0.221 . Therefore, in the short run an increase in the net stable funding ratio reduces return on equity by 22.1 percentage ceteris paribus. 
Table 9. Effect of liquidity risk on financial performance of commercial banks in Kenya

\begin{tabular}{|c|c|c|c|c|c|}
\hline \multirow[b]{2}{*}{ VARIABLES } & \multicolumn{2}{|c|}{ Long Run Model } & \multicolumn{3}{|c|}{ Short Run Model } \\
\hline & Fixed Effects & Random Effects & Naive OLS & Fixed Effects & GMM \\
\hline$R O E_{t-1}$ & & & $\begin{array}{c}0.700^{* * *} \\
(0.0348)\end{array}$ & $\begin{array}{c}0.285^{* * *} * \\
(0.0486)\end{array}$ & $\begin{array}{c}0.530 * * * \\
(0.0777)\end{array}$ \\
\hline NSFR & $\begin{array}{c}-0.213^{* * * *} \\
(0.0786)\end{array}$ & $\begin{array}{c}-0.260 * * * \\
(0.0748)\end{array}$ & $\begin{array}{l}-0.139 * * \\
(0.0563)\end{array}$ & $\begin{array}{c}-0.133^{*} \\
(0.0763)\end{array}$ & $\begin{array}{c}-0.221 * * * \\
(0.0663)\end{array}$ \\
\hline LCR & $\begin{array}{c}-0.0423 \\
(0.120)\end{array}$ & $\begin{array}{c}-0.0454 \\
(0.115)\end{array}$ & $\begin{array}{c}-0.103 \\
(0.0847)\end{array}$ & $\begin{array}{c}-0.0959 \\
(0.119)\end{array}$ & $\begin{array}{c}-0.135 \\
(0.0828)\end{array}$ \\
\hline Constant & $\begin{array}{c}-1.607 * * * \\
(0.126) \\
\end{array}$ & $\begin{array}{c}-1.619^{* * *} * \\
(0.153)\end{array}$ & $\begin{array}{c}-0.445^{* * *} \\
(0.0918) \\
\end{array}$ & $\begin{array}{c}-1.169^{* * * *} \\
(0.149)\end{array}$ & $\begin{array}{c}-0.696^{* * * *} \\
(0.111) \\
\end{array}$ \\
\hline Observations & 381 & 381 & 334 & 334 & 334 \\
\hline R-squared & 0.021 & & 0.594 & 0.122 & \\
\hline Hausman Chi (2) & 4.36 & & & & \\
\hline Wald statistic & & $12.08 * * *$ & & & \\
\hline F statistic & $3.67 * *$ & & 160.97 *** & 13.36 *** & $38.20 * * *$ \\
\hline
\end{tabular}

\section{Discussions}

The results for this study show that net stable funding ratio has a negative impact on banks profitability. NSFR was introduced in the Basel III framework to ensure that banks hold a minimum amount of stable funding based on the liquidity characteristics of their assets and activities over a one year horizon. This reduces maturity mismatches between the asset and liability items on the balance sheet and thereby reduces funding and rollover risk. Our results are inconsistent with results of Said (2014) that there exists positive relationship between NSFR and financial performance. Ashraf et al. (2015) also found a positive and statistically significant relationship between the NSFR and financial stability of banks. However, Dietrich, Hess, and Wanzenried (2014) suggests that short-term investments and reduced maturity should reduce profitability as the longer-term investment and the mismatch of maturity are positively related to the banks' profitability. This might be the case with Kenyan commercial banks where they largely rely on short-term investments and reduced maturity assets which affect profitability negatively. If higher available stable funding which consist of capital and retail deposits is required competitive pressures will constrain banks to some extent resulting in competition for loans, deposits and even the sources of equity and debt investments. This competition will lead to higher costs of doing business resulting in instability.

The coefficient of LCR is -0.045 in the long run with a p-value greater than 0.1 . Therefore, the coefficient is neither significant at 10 , five nor one per cent. In the short run the coefficient is -0.105 and has a p-value greater than 0.1 and is therefore not significantly different from zero at one per cent level of significance. As such either in the long run or in the short run LCR does not influence the financial performance of commercial banks in Kenya holding all else constant. To jointly test whether the components of liquidity risk influenced the financial performance of commercial banks in Kenya Wald test was used to test the joint significance of the coefficients in the random effects model in the long run and the $\mathrm{F}$ test was used in the short run. The test has a null hypothesis that all the coefficients of the components of liquidity risk are jointly equal to zero. Table 6 shows that in the Long run the Wald statistic is 12.08 and is greater than the critical value at one per cent level of significance. Therefore, in the long run the hypothesis that liquidity risk has a significant effect on the financial performance of commercial banks in Kenya is not rejected at one per cent level of significance. In the short run the F statistic is 13.36 and is greater than the critical value at one per cent level of significance. Thus, in the short run the hypothesis that liquidity risk has a significant effect on the financial performance of commercial banks in Kenya is not rejected at one per cent level of significance. Thus, liquidity risk influences financial performance of commercial banks in Kenya both in the short run and in the long run.

These results are in line with the results of studies by Adolphus (2008) and Ahmed et al. (2012), that the there is a negative relationship between bank liquidity and profitability. The results are attributed to the fact that banks hold liquid assets as an obligation to the requirements imposed by the authorities. Holding money for these purposes may lead to low bank profitability as low returns are expected. When a bank has inadequate liquidity, it cannot obtain sufficient funds, either by increasing liabilities or by converting assets promptly, at a reasonable cost, thereby affecting profitability. There is also opportunity cost incurred by liquid assets which might affect profitability negatively. However, the results differ with those of studies by Akhtar (2011) and Wambu (2013) that liquidity risk has a positive relationship with profitability. The differences observed in Wambu (2013) may be explained the periods of study as the current study has a wider scope. 


\section{Conclusions}

Liquidity risk domain consisted of liquidity coverage ratio and net stable funding ratio dimensions. Our findings suggest that NSFR is negatively associated with bank profitability both in long run and short run. Liquidity coverage ratio does not significantly influence the financial performance of commercial banks in Kenya both in long run and short run all else constant. However, the overall effect was that liquidity risk has a negative effect on financial performance. It is therefore advisable for a bank's management to pay the required attention to the liquidity management. While this study provides some insights of the NSFR and liquidity coverage ratio, implications of the new liquidity frameworks proposed by BASEL III warrants further research.

\section{References}

Adolphus, T. J. (2011). Modelling bank management, rural lending and small business finance in Nigeria. Global Journal of Management and Business Research, 11(7). Retrieved from https://globaljournals.org/GJMBR_Volume11/e_journal_GJMBR_Vol_11_ISSUE_7_July.pdf

Ahmed, L. (2015). The effect of foreign exchange exposure on the financial performance of commercial banks in Kenya. International Journal of Scientific and Research Publications, 5(11), 115-120. Retrieved from http://www.ijsrp.org/research-paper-1115/ijsrp-p4718.pdf

Akhtar, M. F., Ali, K., \& Sadaqat, S. (2011). Liquidity risk management: A comparative study between conventional and Islamic banks of Pakistan. Interdisciplinary Journal of Research in Business, 1(1), 35-44. Retrieved from https://globaljournals.org/GJMBR_Volume12/6-Liquidity-Risk-Management.pdf

Angora, A., \& Roulet, C. (2011). Transformation risk and its determinants: A new approach based on the Basel III liquidity management framework. Universite de Limoges. Retrieved from http://iriaf.univ-poitiers.fr/colloque2011/article/j1s2a2.pdf

Ashraf, D., L'Huillier, B., \& Rizwan, M. S. (2015). Does the implementation of a Net Stable Funding Ratio enhance the financial stability of the banking industry? An international study. Retrieved from https://acfr.aut.ac.nz/_data/assets/pdf_file/0003/29766/B-LHuillier-V9-Does-the-implementation-of-a-NSF R-enhance-the-financial-stability.pdf

Bordeleau, E., Crawford, A., \& Graham, C. (2009). Regulatory Constraints on Bank Leverage: Issues and Lessons from the Canadian Experience. Bank of Canada Discussion Paper 2009-15. Retrieved from http://www.banqueducanada.ca/wp-content/uploads/2010/01/dp09-15.pdf

Brunnermeier, M. K., \& Yogo, M. (2009). A note on liquidity risk management (No. w14727). National Bureau of Economic Research. https://doi.org/10.1257/aer.99.2.578

Central Bank of Barbados. (2008). Liquidity risk management guideline, bank supervision. Bridgetown.: Central Bank of Barbados. Retrieved from http://www.centralbank.org.bb/banking-supervision/regulatory-framework/regulatory-guidelines

Diamond, D. W., \& Rajan, R. G. (2005). Liquidity shortages and banking crises. The Journal of Finance, 60(2), 615-47. https://doi.org/10.1111/j.1540-6261.2005.00741.x

Dietrich, A., Hess, K., \& Wanzenried, G. (2014). The good and bad news about the new liquidity rules of Basel III in Western European countries. Journal of Banking \& Finance, 44, 13-25. https://doi.org/10.1016/j.jbankfin.2014.03.041

Drehmann, M., \& Nikolaou, K. (2013). Funding liquidity risk: definition and measurement. Journal of Banking \& Finance, 37(7), 2173-2182. https://doi.org/10.1016/j.jbankfin.2012.01.002

Drigă, I., \& Dura, C. (2014). The Financial Sector and the Role of Banks in Economic Development. In 6th International Multidisciplinary Symposium "Universitaria SIMPRO (pp. 10-11). Retrieved from http://www.upet.ro/simpro/2014/proceedings/09\%20-\%20ECONOMICS\%20AND\%20PUBLIC\%20ADMI NISTRATION/9.2.pdf

Falconer, B. (2001). Structural liquidity: The worry beneath the surface. Balance Sheet, 9(3), 13-19. https://doi.org/10.1108/09657960110695998

Galvao, A. F., Montes-Rojas, G., Sosa-Escudero, W., \& Wang, L. (2013). Tests for skewness and kurtosis in the one-way error component model. Journal of Multivariate Analysis, 122, 35-52. https://doi.org/10.1016/j.jmva.2013.07.002

Giannotti, C., Gibilaro, L., \& Mattarocci, G. (2011). Liquidity risk exposure for specialised and unspecialised real estate banks: Evidence from the Italian market. Journal of Property Investment \& Finance, 29(2), 98-114. 
https://doi.org/10.1108/14635781111112756

Giordana, G., \& Schumacher, I. (2011). The impact of the Basel III liquidity regulations on the bank lending channel: A Luxembourg case study (No. 61). Central Bank of Luxembourg. Retrieved from https://www.researchgate.net/publication/254391400_The_Impact_of_the_Basel_III_Liquidity_Regulations _on_the_Bank_Lending_Channel_A_Luxembourg_case_study

Goodhart, C. (2008). Liquidity risk management. Banque de France Financial Stability Review, 11, 39-44. Retrieved from http://econpapers.repec.org/article/bfrfisrev/2008_3a11_3a6.htm

Hosna, A., Manzura, B., \& Juanjuan, S. (2009). Credit risk management and profitability in commercial banks in Sweden. Rapport nr: Master Degree Project 2009, 36. Retrieved from https://gupea.ub.gu.se/handle/2077/20857

Koziol, C., \& Lawrenz, J. (2009). What makes a bank risky? Insights from the optimal capital structure of banks. Journal of Banking \& Finance, 33(5), 861-873. https://doi.org/10.1016/j.jbankfin.2008.09.022

Maaka, Z. A. (2013). The relationship between liquidity risk and financial performance of commercial banks in Kenya (Doctoral dissertation, University of Nairobi). Retrieved from http://erepository.uonbi.ac.ke/bitstream/handle/11295/60295/Maaka_The\%20relationship\%20between\%20li quidity $\% 20$ risk\%20and $\% 20$ financial\%20performance.pdf?sequence $=3$

Musembi, D. M., Ali, B., \& Kingi, W. (2016). Effect of Liquidity Risk Determinants on the Financial Performance of Commercial Banks Listed at the Nairobi Securities Exchange. Imperial Journal of Interdisciplinary Research, 2(11). Retrieved from http://www.onlinejournal.in/IJIRV2I11/334.pdf

Ogboi, C., \& Unuafe, O. K. (2013). Impact of credit risk management and capital adequacy on the financial performance of commercial banks in Nigeria. Journal of Emerging Issues in Economics, Finance and Banking, 2(3), 703-717. Retrieved from http://globalbizresearch.org/economics/images/files/22882_JEIEFB_OGBOI_Charles_UNUAFE_Okaro\%2 0Kenneth.pdf

Ogilo, F., \& Mugenyah, L. O. (2015). Determinants of Liquidity Risk of Commercial Banks in Kenya. The International Journal of Business \& Management, 3(9), 469-473. Retrieved from http://www.theijbm.com/force_download.php?file_path=wp-content/uploads/2015/10/49.-BM1509-034.pdf \&id $=1953$

Ogol, G. O. (2011). Liquidity risk management practices in microfinance institutions in Kenya (Doctoral dissertation, School of Business, University of Nairobi).

Ouma, T. M. (2015). Effects of liquidity risk on profitability of commercial banks in Kenya (Doctoral dissertation, University of Nairobi). Retrieved from http://erepository.uonbi.ac.ke/bitstream/handle/11295/94460/Tom_Effects\%20of\%20liquidity\%20risk\%20o n\%20profitability\%20of\%20commercial\%20banks\%20in\%20Kenya.pdf?sequence=1

Plochan, P. (2007). Risk management in banking. Bratislava: University of Economics in Bratislava.

Said, R. M. (2014). Net Stable Funding Ratio and Commercial Banks Profitability. International Proceedings of Economics Development and Research, 76, 34. Retrieved from http://www.imf.org/external/pubs/ft/wp/2014/wp14106.pdf

Said, R. M., \& Tumin, M. H. (2011). Performance and financial ratios of commercial banks in Malaysia and China. International Review of Business Research Papers, 7(2), 157-169. Retrieved from https://www.bizresearchpapers.com/11.\%20Rasidah-FINAL.pdf

Wambu, T. M. (2013). The relationship between profitability and liquidity of commercial banks in Kenya (Doctoral dissertation, University of Nairobi). Retrieved from http://erepository.uonbi.ac.ke/bitstream/handle/11295/58668/Wambu_The\%20relationship\%20between\%20 profitability $\% 20$ and $\% 20$ liquidity $\% 20$ of $\% 20$ commercial $\% 20 \mathrm{banks} \% 20 \mathrm{in} \% 20 \mathrm{Kenya}$.pdf?sequence $=3$

\section{Copyrights}

Copyright for this article is retained by the author(s), with first publication rights granted to the journal.

This is an open-access article distributed under the terms and conditions of the Creative Commons Attribution license (http://creativecommons.org/licenses/by/4.0/). 